\title{
Analysis of the current state of public passenger transport in the area of Dubrovnik
}

DOI: https://doi.org/10.7307/ptsm.2020.3

\author{
Davor Brčić ${ }^{1}$, Božo Radulović ${ }^{1}$ \\ Faculty of Transport and Traffic Sciences ${ }^{1}$
}

\section{Keywords:}

Public transport

Suburban transport

Transport demand

Dubrovnik

Public transport line

\begin{abstract}
Public transport is of great importance for the development of urban and suburban areas, so high importance is attached to the analysis of the current situation in order to identify certain shortcomings and room for improvement. The area of Dubrovnik is of a specific character, apart from its location along the coast, it has the character of a very attractive tourist centre. This paper will present the results of the analysis of the organization of public transport in this area and present certain conclusions from it.
\end{abstract}

\section{Introduction}

Public transportation (also called mass transportation) is the movement of people within urban areas using group travel technologies such as bus, train, subway and tram [1] Public transport in the area of Dubrovnik is organized as a bus transport, and is carried out by the transport company Libertas d.o.o. The article is based on the data of a study prepared by the Faculty of Transport and Traffic Sciences entitled "Study analysis of urban, suburban and county lines performed by the company Libertas d.o.o. with a proposal of timetables and work schedules of drivers". The second chapter presents the scope of the research. The third chapter refers to the research methodology used in making the analysis of the current situation. The fourth chapter presents the results of the research, and at the end a discussion and conclusion are presented.

\section{Catchment area}

Dubrovačko-neretvanska County is the southernmost County in the Republic of Croatia and is territorially organized into 22 units of local government and self-government, i.e. 5 cities (Dubrovnik, Korčula, Ploče, Metković and Opuzen) and 17 municipalities (Blato, Dubrovnik coast, Janjina, Konavle, Kula Norinska, Lastovo, Lumbarda, Mljet, Orebić, Pojezerje, Slivno, Smokvica, Ston, Trpanj, Vela Luka, Zažablje and Župa dubrovačka). The county center is located in the City of Dubrovnik. [2]

Dubrovačko-neretvanska County covers a total area of $9272 \mathrm{~km} 2(10.32 \%$ of the total area of the Republic of Croatia), of which $1782 \mathrm{~km} 2$ refers to the land territory of the county, and $7490 \mathrm{~km} 2$ maritime territory. [4]. 


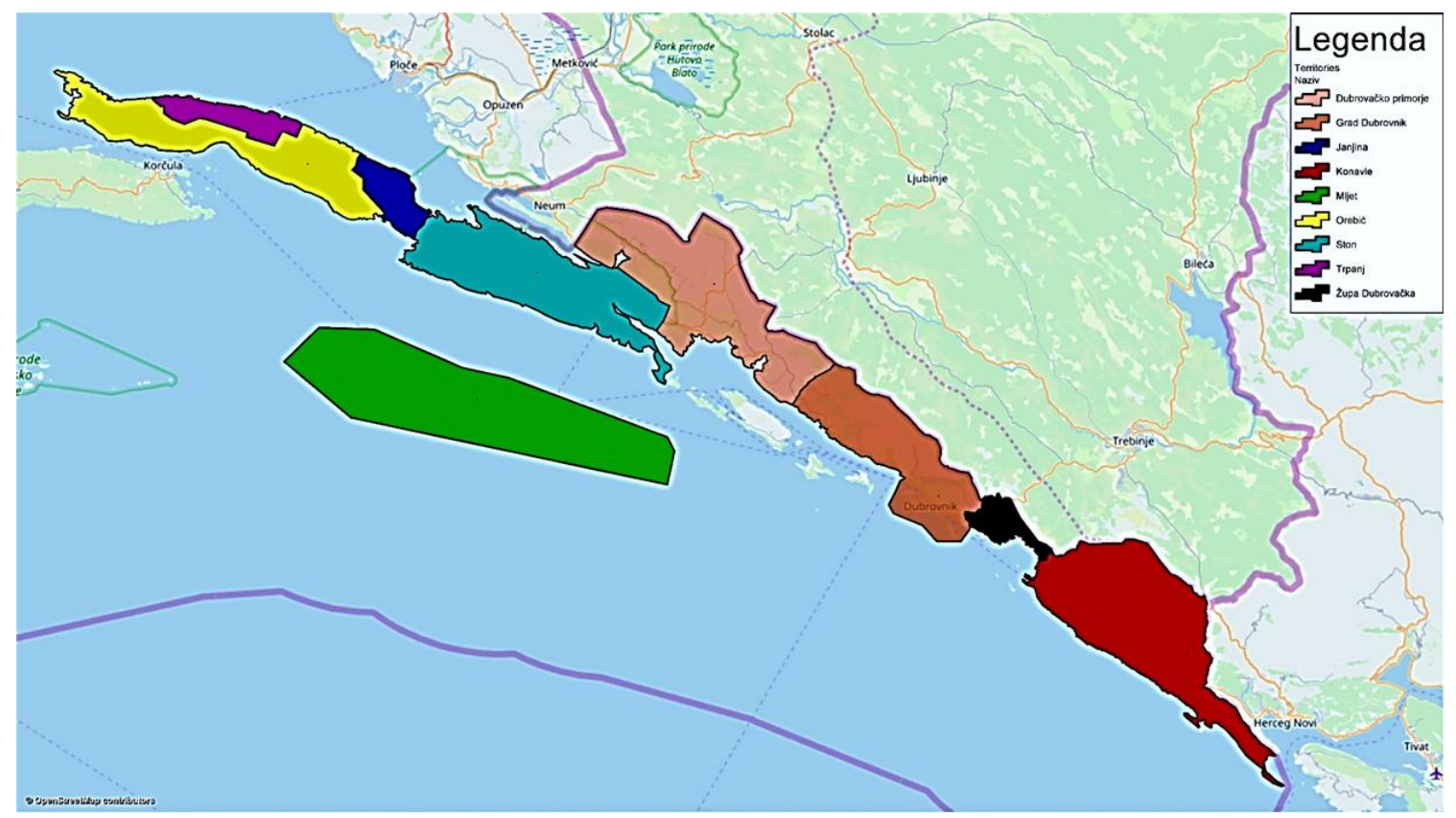

Figure 1. Cartographic representation of the coverage area Source: [3]

Public passenger transport company Libertas d.o.o. performs in the administrative area of the City of Dubrovnik and in all municipalities located in the Dubrovačko-neretvanska County. The division of the lines follows below [3]:

a total of 25 city/urban (utility) lines within the City of Dubrovnik and two municipalities (Konavle and Mljet), with a total of 844 departures during the working day, 843 departures during Saturday and 803 departures on Sundays and holidays during the autumn period;

$>703$ departures during the working day, 667 departures on Saturdays and 551 departures on Sundays and public holidays during the winter period under the Public Service Agreement between the City of Dubrovnik and Libertas Dubrovnik;

$>$ on 19 county (suburban) lines based on permits obtained from the competent office of the DubrovnikNeretva County with 171 departures during the day according to the official data of Libertas d.o.o. from Dubrovnik.

\section{Methodology}

For the purposes of the research, data obtained from the company Libertas Dubrovnik were used. The data refer to the routes of the lines, the number of vehicles per line, the number and location of stops, and the number of transported passengers. [3]

Based on the obtained data, with the help of the software tool GIS (Geographic information system), the following was created:

$>$ graphical representation of network lines;

$>$ graphical representation of locations, and the gravitational area of terminals and stops;

$>$ display of the load of city lines in the autumn and winter period of observation. 


\section{Results of public transport research in the area of the City of Dubrovnik}

\section{Urban passenger transport}

According to the analysis of the data submitted by Libertas d.o.o., the basic data of city (utility) lines are shown in Table 1.

Table 1. Basic data of city lines for 2018

\begin{tabular}{|c|c|c|c|c|c|}
\hline \multicolumn{2}{|r|}{ Line } & $\begin{array}{l}\text { Number of } \\
\text { vehicles per } \\
\text { line }\end{array}$ & $\begin{array}{c}\text { Line length in } \\
\mathrm{Km}\end{array}$ & $\begin{array}{c}\text { Number of } \\
\text { stops }\end{array}$ & $\begin{array}{l}\text { Number of } \\
\text { transported } \\
\text { passengers }\end{array}$ \\
\hline 1 & Pile - Autobusni kolodvor & 1 & 6 & 14 & 10.492 \\
\hline $1 \mathrm{~A}$ & Pile - Stara Mokošica & 4 & 27 & 36 & 1.562 .555 \\
\hline $1 \mathrm{~B}$ & Pile - Nova Mokošica & 4 & 26 & 35 & 1.340 .933 \\
\hline $1 \mathrm{C}$ & Pile - Mokošica & 1 & 23 & 32 & 51.722 \\
\hline $1 \mathrm{D}$ & Lozica - Kantafig & 1 & 14 & 4 & 769 \\
\hline $1 \mathrm{E}$ & Shuttle bus AK - Pile & 1 & 13 & 8 & 15.143 \\
\hline 2 & Pile - Gorica & 1 & 11 & 26 & 186.189 \\
\hline $2 \mathrm{~A}$ & Glavica B. Kuk - Pile & 1 & 10 & 23 & 154.809 \\
\hline 3 & Pile - Nuncijata & 1 & 14 & 23 & 572.305 \\
\hline $3 \mathrm{~A}$ & Nuncijata - Pile & 2 & 11 & 14 & 73.658 \\
\hline 4 & Pile - H. Pallace & 1 & 9 & 24 & 1.097 .949 \\
\hline 5 & H. Neptun - Viktorija & 3 & 17 & 38 & 187.425 \\
\hline 6 & Pile - Babin Kuk & 1 & 10 & 23 & 2.332 .819 \\
\hline 8 & Kantafig - Babin Kuk & 5 & 12 & 25 & 331.439 \\
\hline 8 & Viktorija - Gruž & 1 & 10 & 23 & 578.893 \\
\hline 9 & Pile - O. bolnica & 2 & 8 & 20 & 156.254 \\
\hline 17 & Bosanka-Pile & 1 & 28 & 18 & 35.673 \\
\hline $17 \mathrm{~A}$ & Šumet - Komolac & 1 & 12 & 7 & 0 \\
\hline 20 & Šipan & 1 & 5 & 2 & 0 \\
\hline 28 & DBK - Osojnik & 1 & 19 & 17 & 14.108 \\
\hline 35 & Brsečine - Dubrovnik & 1 & 48 & 21 & 68.010 \\
\hline \multicolumn{2}{|c|}{ In total } & 36 & 335 & 433 & 8.771.145 \\
\hline
\end{tabular}

Source: [3]

Based on the obtained data and their processing, it is evident that over 2,840,000 car kilometers are realized on city lines in a year (2018).

An additional reason for such values is the large impact of return trips due to the characteristics of the lines (radial type of line). Figure 2 graphically shows the routes of all city (communal) lines, except lines 35 (Dubrovnik Brsečine) and 28 (Dubrovnik - Osojnik). 


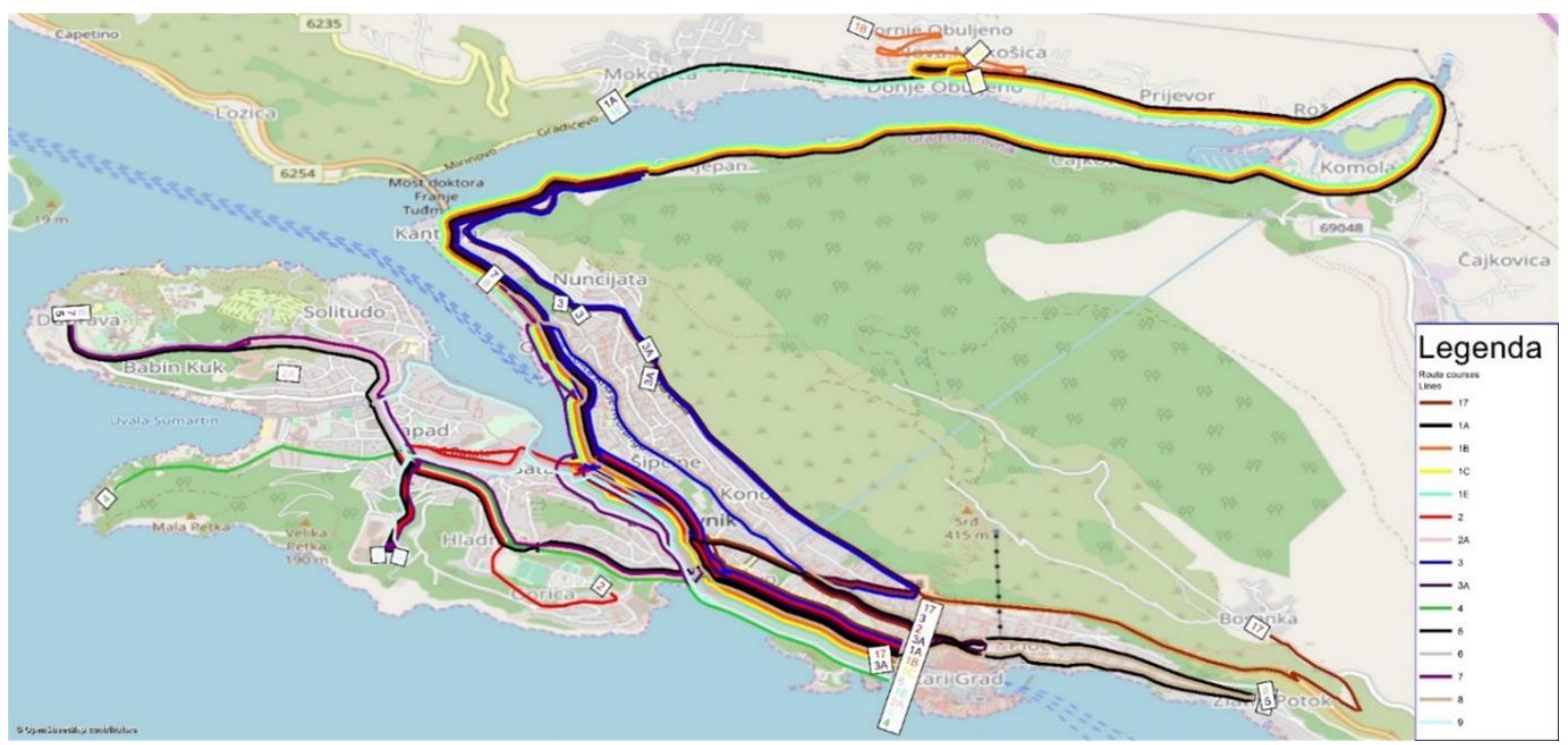

Figure 2. Graphic representation of the city line network Source: [3]

Figure 3 shows the locations of terminals that use city (utility) lines. The picture shows that all terminals are located on the outskirts or in the centers of the settlement, while only the Pile terminal is located in the center of the City of Dubrovnik.

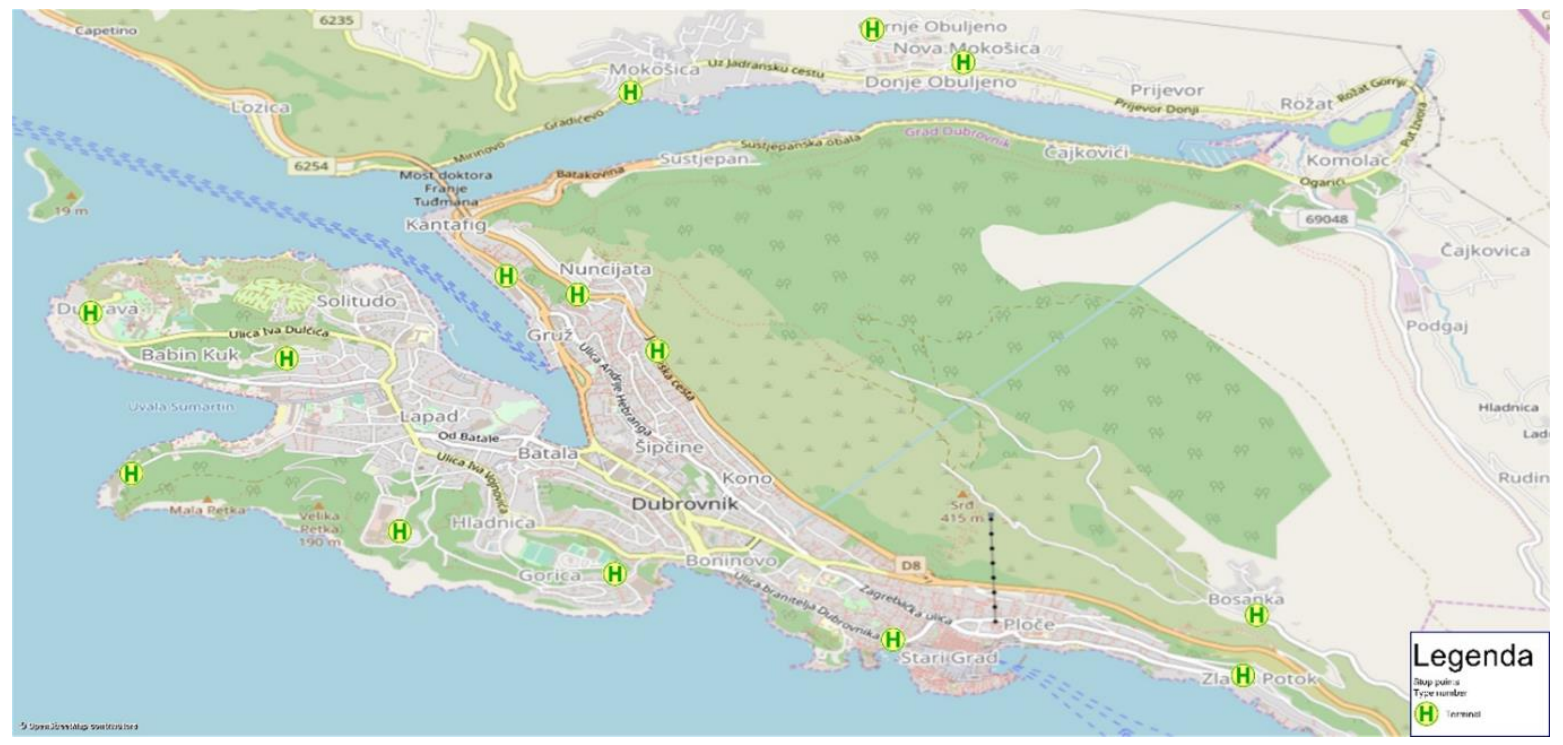

Figure 3. Graphic representation of terminal locations in the area of the City of Dubrovnik Source: [3]

The locations of stops for city (communal) lines are graphically shown in Figure 3. Taking into account that there are more than a hundred bus stops in the City of Dubrovnik and that in most cases their mutual distance is not more than 300 meters (Figure 4), it can be concluded that availability of public passenger transport (bus stops) in the City of Dubrovnik is very good. 


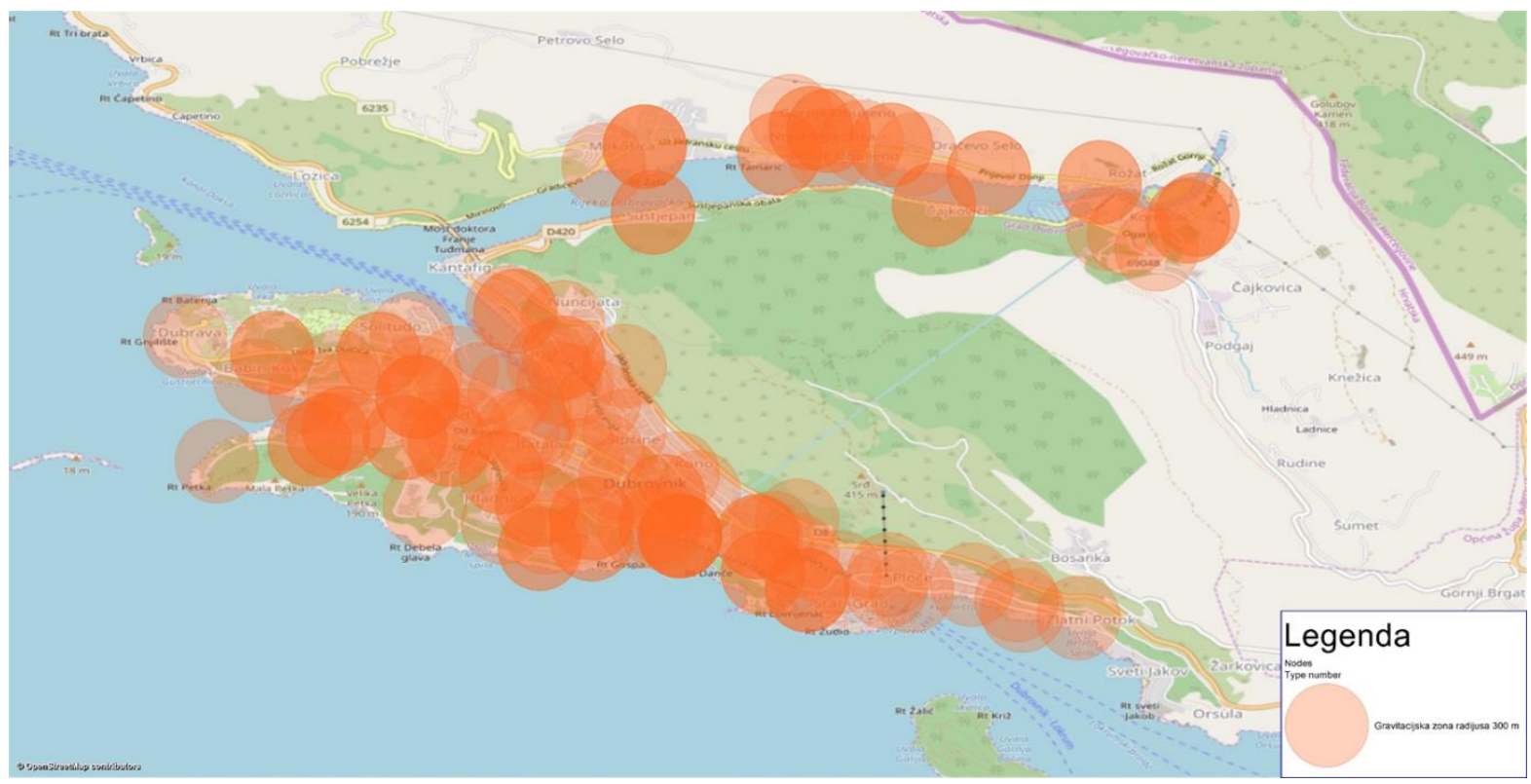

Figure 4. Graphic representation of the gravity area (300 meters) of the stop together with the locations of the terminals in the area of the City of Dubrovnik

\section{Source: [3]}

Figure 4 graphically shows the load of the network of city (utility) lines during the characteristic month during the autumn period (October 2018). It can be seen from the picture that the busiest route is towards Babin Kuk (in both directions) and towards Mokošica and Hotel Palace.

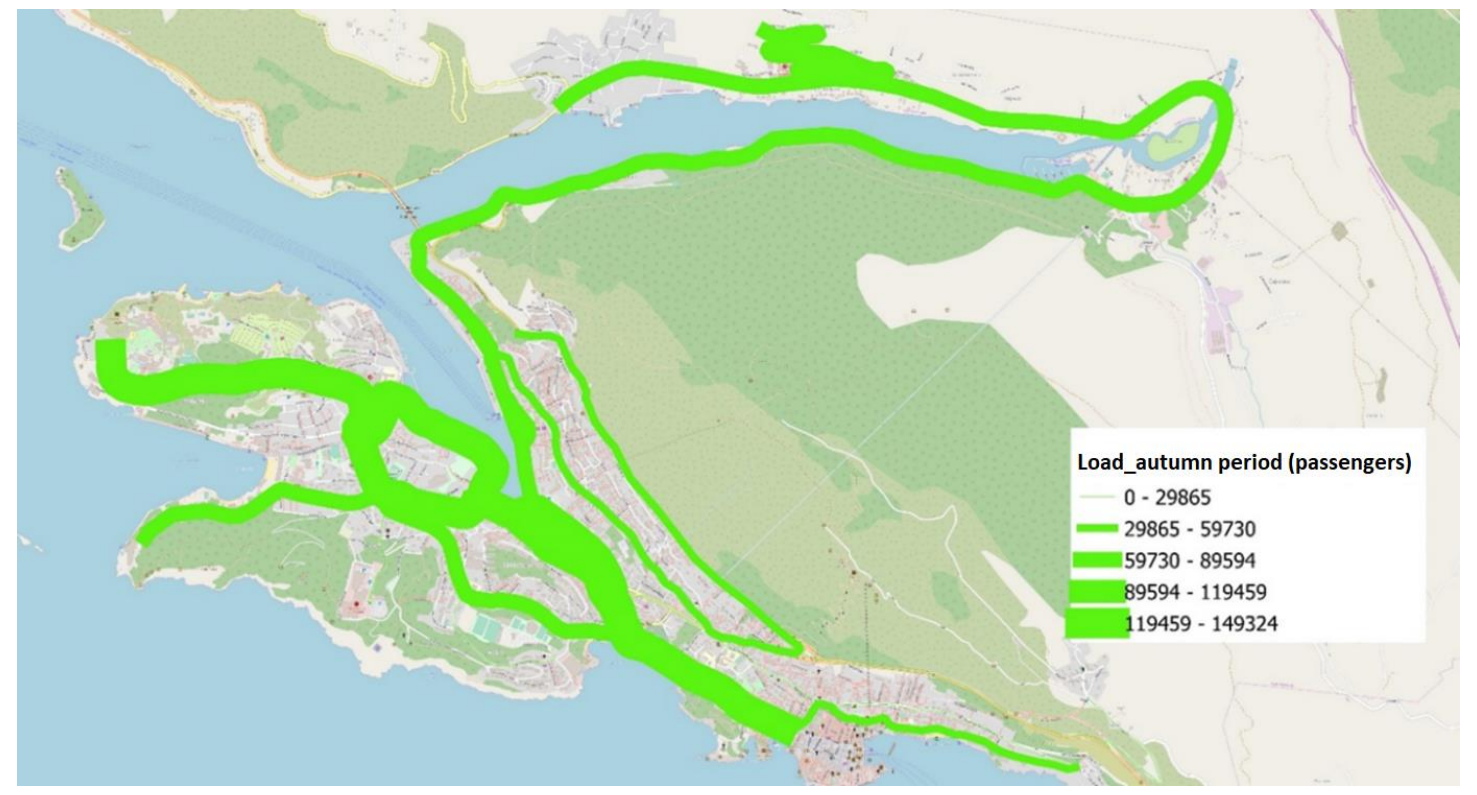

Figure 5. Load of city lines in the autumn period (October 2018)

\section{Source: [3]}

Figure 5 graphically shows the load of the network of city (utility) lines during the characteristic month during the autumn period (October 2018). It can be seen from the picture that the busiest route is towards Babin Kuk (in both directions) and towards Mokošica and Hotel Palace.

Comparing the two periods, there is a large difference in load (number of transported passengers) between autumn and winter, ie the number of transported passengers is three times higher in the characteristic month of the autumn 
period than the characteristic month of the winter period (Figure6). Oscillations in transport demand are caused by a decrease in tourist activity (arrival of tourists), which is predominantly the primary economic activity in the area of the City of Dubrovnik.

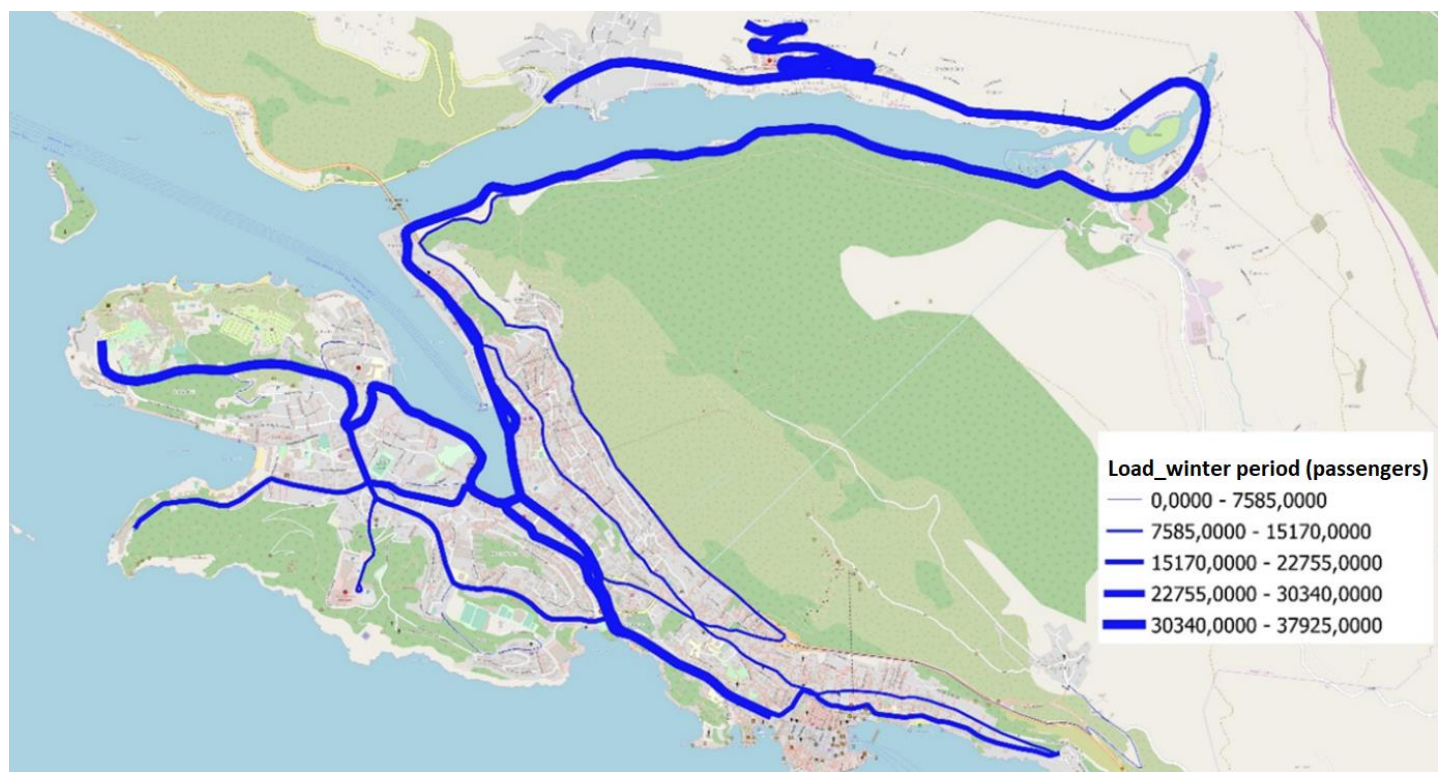

Figure 6. Load of city lines in winter (January 2019)

Source: [3]

\section{Suburban passenger transport}

The network of suburban bus lines consists of 19 county lines whose departures and terminals are determined in advance by permits issued by the competent state administration office in the Dubrovačko-neretvanska County. The routes of suburban (county) lines cover all major settlements east of the City of Dubrovnik.

During 2018, suburban (county) lines achieved a total of over 1,900,000 road kilometres and transported 1,437,141 passengers (according to Libertas d.o.o.). The busiest line is number 10 (Dubrovnik - Cavtat), and its share is more than $25 \%$ in the total mileage of all suburban lines, while they carried 730,129 passengers. [3]

Table 2. Basic data of suburban lines for 2018

\begin{tabular}{|l|l|l|l|l|l|l|}
\hline \multicolumn{2}{|c|}{ Line } & Mileage & $\begin{array}{c}\text { Number } \\
\text { of vehicles } \\
\text { per line }\end{array}$ & $\begin{array}{c}\text { Line length } \\
\text { in Km }\end{array}$ & $\begin{array}{c}\text { Number of } \\
\text { stops }\end{array}$ & $\begin{array}{c}\text { Number of } \\
\text { transported } \\
\text { passengers }\end{array}$ \\
\hline 10 & DBK - Cavtat & 519.899 & 4 & 22 & 9 & 730.129 \\
\hline 11 & DBK - Molunat & 90.662 & 4 & 45 & 15 & 61.339 \\
\hline 12 & DBK - Slano & 186.959 & 4 & 36 & 9 & 85.092 \\
\hline 15 & DBK - Ston & 119.755 & 1 & 56 & 14 & 47.724 \\
\hline 16 & DBK - Plat & 181.638 & 1 & 16 & 7 & 188.912 \\
\hline $16 \mathrm{~A}$ & Dubrovnik - Srebreno & 112.314 & 1 & 14 & 5 & 103.531 \\
\hline 18 & Pomena - Sobra & 29.841 & 2 & - & - & 0 \\
\hline 19 & Pomena - Saplunara & 15.825 & 1 & - & - & 0 \\
\hline 21 & DBK - Orebić & 88.897 & 1 & 113 & 22 & 25.577 \\
\hline 22 & DBK - Imotica & 47.756 & 1 & 71 & 22 & 11.508 \\
\hline 23 & DBK - Buići & 30.507 & 1 & 18 & 11 & 22.449 \\
\hline $23 \mathrm{~A}$ & Dubrovnik - Srebreno & 75.491 & 1 & 22 & 11 & 22.086 \\
\hline 25 & DBK - Vodovađa & 91.526 & 1 & 45 & 16 & 38.199 \\
\hline
\end{tabular}


Brčić, D.., Radulović, B. / Public Transport \& Smart Mobility 2020, 25-32

\begin{tabular}{|l|l|l|l|l|l|l|}
\hline 26 & DBK - Majkovi & 83.060 & 1 & 32 & 10 & 16.321 \\
\hline $27 / 27 \mathrm{~A}$ & DBK - Vitaljina & 107.648 & 1 & 49 & 17 & 51.237 \\
\hline 29 & Duba - Cavtat & 32.962 & 1 & - & - & 3.535 \\
\hline 30 & Vodovođa - Cavtat & 28.880 & 1 & - & - & 3.029 \\
\hline 31 & Vitaljina - Cavtat & 67.079 & 1 & - & - & 12.016 \\
\hline 38 & Dubrovnik - Gruda & 21.237 & 1 & 34 & 20 & 14.457 \\
\hline In total & $\mathbf{1 . 9 3 1 . 9 3 6}$ & $\mathbf{2 9}$ & $\mathbf{5 7 3}$ & $\mathbf{1 8 8}$ & $\mathbf{1 . 4 3 7 . 1 4 1}$ \\
\hline
\end{tabular}

Source: [3]

Lines that cover more than 100,000 kilometres on an annual basis and carry from about 50,000 to over 100,000 passengers are:

$>$ Line 12 (Dubrovnik - Slano);

$>$ Line 15 (Dubrovnik - Ston);

$>$ Line 16 (Dubrovnik - Plat);

$>$ Line 16A (Dubrovnik - Srebreno);

$>$ Line 27/27A (Dubrovnik - Vitaljina).

Comparing the number of travelled kilometres with the number of transported passengers on individual lines (Table 2), it can be seen that on part of the suburban (county) lines there is less than one transported passenger per kilometre. [3]

It can be stated that the above data indicate a disproportionately large transport supply in relation to transport demand (number of passengers).

Assuming that the transport on the suburban (county) lines is conditioned due to the strong gravity zone of the City of Dubrovnik, a significant subsidy of certain municipalities is necessary in which the transport demand is low to the carrier Libertas d.o.o. Otherwise, for some suburban (county) lines there is no economic justification for operational use.

\section{Discussion}

The main attractors of travel on the transport network are the central terminal Pile (Old Town) where most of the administrative, catering and cultural sights of the City of Dubrovnik are located, while the producers are: Babin Kuk (a large number of hotels are in the area or in that direction), Luka Gruž (seaport, bus station and cruise port) and the settlement of Mokošica (mostly residential buildings with the purpose of housing). Precisely on these routes are the main roads in the City of Dubrovnik, which are accordingly roads with higher capacity with the offered higher quality of service. [3]

The analysis of transported passengers on city (utility) lines shows that the average number of transported passengers per year (2018) per kilometre is 3.1 passengers / $\mathrm{km}$. This data shows that the network of city (utility) lines is dispersed with relatively long lines, so it follows that although many passengers are transported during the year, the average number of passengers per kilometre is not large. The routes of city lines are conceived as radial lines that connect the city centre with the peripheral parts of the city. [3]

Public transport terminals also follow the concept of radial lines where the Pile terminal is the central terminal and the starting point towards other destinations or terminals. Public transport lines for city (utility) lines and bus stops are positioned in such a way that their gravity zone covers the entire city. Therefore, the entire area of the City of Dubrovnik is very well served by public regular passenger transport. [3]

The load of the lines shows a large influence of the dominant lines (lines 1A, 1B, 4 and 6) which achieve most of the transport performance during the year. It is also necessary to note that a large oscillation was observed in the number of transported passengers between summer - autumn and winter. [3] 
Transport demand on suburban (county) lines is significantly lower than on city (communal) lines, which is indicated by the fact that on average less than one passenger travels per kilometre per year. Suburban lines are divided into western and eastern suburban lines that serve all major settlements in the Dubrovačko-neretvanska County. Therefore, the fact remains that the operation of suburban lines engages Libertas d.o.o. significant resources (buses) and human resources (drivers - traffic service and other employees). [3]

\section{Conclusion}

Public transport in the area of the City of Dubrovnik and surrounding municipalities located in the area of Dubrovačko-neretvanska County is performed by the carrier Libertas d.o.o. which is in the public domain. In total, transport is performed on 35 different types of lines, a significant part of which refers to county lines (19), while by far the most departures are made on city (utility) lines.

It should be noted that on the road network of the City of Dubrovnik there has been a disparity between transport demand (especially in season) and the capacity of roads and intersections for many years. The high density of the total traffic flow on the road network affects the reduction of the quality of public transport of passengers in the area of the City of Dubrovnik, since public transport does not have special and separate lanes, i.e. there is no secured priority at intersections.

Uneven transport demand puts a heavy burden on Libertas d.o.o. in the operational organization of the traffic process, both in human resources (traffic service, drivers, maintenance service) and in material resources (buses and vehicle maintenance facilities).

\section{References}

[1] Brčić D., Slavulj M. Urbana mobilnost. Fakultet prometnih znanosti. Zagreb. 2019.

[2] Libertas - Dubrovnik d.o.o. Potpuni tekst. Društveni ugovor 27. lipnja 2018. Dubrovnik. 2018.

[3] Faculty of Transport and Traffic Sciences. Studijska analiza gradskih, prigradskih i županijskih linija koje obavlja tvrtka Libertas d.o.o. s prijedlogom voznih redova i rasporeda rada vozača. Faculty of Transport and Traffic Sciences. Zagreb. 2020.

[4] DUNEA. Županijska razvojna strategija Dubrovačko-neretvanske županije 2016.-2020. Dubrovačkoneretvanska županija. Dubrovnik. 2016. 